\title{
Amenity Trees Diversity in Selected Tertiary Institutions within Port Harcourt Metropolis, Rivers State, Nigeria
}

\author{
OLADELE, AT; *EGUAKUN, FS; UGBAJA, UC \\ Department of Forestry and Wildlife, University of Port Harcourt, Rivers State, Nigeria \\ *Corresponding Author Email: funmilayo.popo-ola@uniport.edu.ng
}

\begin{abstract}
Trees are a central component of most urban communities, providing diverse benefits such as improving air quality, increasing aesthetic appeal, preventing erosion and providing habitat for wildlife. However, there is inadequate information on the distribution and diversity of these trees within our academic environments. This study investigates the distribution, frequency and species diversity of amenity trees within the main campuses of tertiary institutions in River State, Nigeria. The selected tertiary institutions are University of Port-Harcourt (Institution A) and Rivers State University (Institution B). Five (5) major roads in each campus were randomly selected, and 200m along each road was selected as sample areas. Ten (10) meter was marked from the edge of the road, and complete inventory was taken of all trees within the marked sample area. Diameter at breast height (DBH), crown diameter and tree height were measured. Shannon-Weiner and Simpson diversity index were used to calculate amenity trees diversity, while Margalef specie richness was used to calculate the species index. A total of 539 trees were surveyed on both campuses, comprising 26 different species and 10 families. Casuarina equisetifolia had the highest frequency with 92 trees in B. Simpson diversity index showed higher diversity $(\mathrm{D}=0.78)$ in $\mathrm{B}$ amenity trees than $\mathrm{A}(\mathrm{D}=0.81)$. Shannon-Weiner species evenness was 0.71 and 0.76 for Institutions A and B respectively. Margalef specie richness index were 2.90 for $\mathrm{A}$ and 1.40 for B. This study provides baseline information for ecosystem management of urban forest tree species within campuses. For sustainable management of trees on campuses, frequent inventory and survey should be conducted to establish their abundance, distribution and diversity.
\end{abstract}

DOI: https://dx.doi.org/10.4314/jasem.v24i12.25

Copyright: Copyright (C) 2020 Oladele et al. This is an open access article distributed under the Creative Commons Attribution License (CCL), which permits unrestricted use, distribution, and reproduction in any medium, provided the original work is properly cited.

Dates: Received: 10 October 2020; Revised: 30 November 2020; Accepted: 20 December 2020

Key words: Amenity, Biodiversity indices, Conservation, Tree diversity

Trees are the unsung heroes of our urban environment whose roles cannot be over emphasized. They provide countless services such as conservation of species, soil erosion control and flora and fauna habitat preservation (Armenteras et al., 2009). According to Ezeabasili et al., (2015) urban forestry involves the planting and maintaining of a group of trees within a built environment. These built environments could be cities, residential towns, institutional areas such as schools, churches, mosques etc. Trees in academic institutions located in cities are part of urban forests (Raji and Babalola, 2018). University of Port Harcourt is a typical urban environment. Over the years, urban environment has experienced tremendous increase in human population which has led to different anthropogenic disturbance on the trees (Omoro et al., 2010). The University being an academic area is highly populated and is an example of a typical urban environment. The report of United-Nations (2006) stated that over the next four decades all of the world's population growth will occur in urban areas and over 60 percent of the global population will reside in urban areas. Kumar et al., (2006) started that management interventions is required to maintain the overall biodiversity, productivity, and sustainability. All over the world, overexploitation has been noted as a major environmental and economic problem resulting in the rapid loss of tree diversity (Mani and Parthasarathy, 2006). Suratman (2012), stated that information on composition, diversity of tree species and species-rich communities is of key importance in the planning and implementation of biodiversity conservation efforts. Diversity is an indicator that allows appreciating links between the richness and the abundance of individuals' trees; it reflects the degree of heterogeneity or stability of vegetation. Biodiversity conservation depends basically on the knowledge of the structure, species richness, and the ecological characteristics of vegetation. Quantitative information of these variables is important in understanding the status of the forest estate, decision-making, planning and implementation of conservation strategy (Suratman, 2012). Ogwu et al., (2016) reported that sustainable development advocates that humans and biodiversity coexist side by side. A university campus should be promoted as a model environment for 
sustainable development. Knowledge on tree species diversity and distribution would serve as baseline information to know the status of the tree species in the study area; which is basic in understanding regeneration processes, such as tree growth, tree mortality, under-storey development, and the spread of disturbances (Francisco et al., 2017). To protect and prevent trees decline in our urban environment, it is essential to examine the current status of species diversity, composition and abundance of tree species as this will provide guidance for management and conservation. This study is aimed at assessing tree species diversity and distribution within two tertiary institutions in Port Harcourt, Rivers State, Nigeria with the view to providing baseline information useful to developing conservation strategy.

\section{MATERIALS AND METHOD}

Study area: The study was conducted in two universities (One federal and one state) in Port Harcourt; University Park, University of Port Harcourt (A) and the main campus of the Rivers State University of Science and Technology (B). The University of Port Harcourt, Choba is located in Ikwerre local government area of Rivers state, Nigeria. It lies between latitude $04^{\circ} 53^{\prime} 38.3^{\prime \prime} \mathrm{N}$ and longitude $06^{\circ} 54^{\prime} 38^{\prime \prime}$ E. Rivers State University of Science and Technology is located at Nkpolu-Oroworuko Community in Port Harcourt, the capital of Rivers State, Nigeria. It lies between latitude $4^{\circ} 47^{\prime} 21^{\prime \prime} \mathrm{N}$ and longitude $6^{\circ} 59^{\prime} 54^{\prime \prime} \mathrm{E}$. The university was established in October, 1980 from the Rivers State College of Science and Technology. It is the first Technological University in Nigeria, and the first state owned State University in the Niger Delta region of Nigeria. Port Harcourt lies in the southern Niger delta area of Nigeria, in Rivers state. It rests in the mangrove swamp forest vegetation. The city has a tropical climate characterized by a rainy season between April and October, and a cold drier season between January and March.

Data collection: Data for this study were collected through sampling the avenue roads in the main campuses of the universities. 200 meters each of five major roads in each campus was selected through a random sampling and data were collected from the amenity trees in the selected roads. The service of Taxonomist was employed in the identification of the trees species. Each of the trees found in the campuses were identified to species level with their scientific name, local name and family. Tree growth parameters were measured on the trees. The measured parameter includes tree height, diameter at breast height and crown diameter. Stem diameters, crown diameter and total height were measured using diameter tape, meter tape and Haga altimeter respectively.

Data analysis: Plant population and species diversity were analyzed using the following species diversity indices:

Shannon-Weiner Index of Diversity (H') - Species diversity within the study area were analyzed using the diversity index of Shannon and Weaver (1949), the index varies depending on the number of species present. It is higher when there are more species, indicating greater diversity. Shannon-Weiner Index of diversity $\left(\mathrm{H}^{\prime}\right)$ was calculated following Kent and Coker (1992) and Magurran (2004):

$$
H^{\prime}=-\Sigma p_{i} \ln p_{i}
$$

Where: $P_{i}=\frac{S}{N} \mathrm{~S}=$ number of individuals of one species; $\mathrm{N}=$ total number of all individuals in the site and $\mathrm{In}=$ logarithm to base e

Simpson index is a measure of species dominance. As biodiversity increases, the Simpson index decreases. Therefore to get a clear picture of species dominance, simpson index is given as; (Simpson, 1949)

$$
D_{s}=1-\frac{\sum n_{i}\left(n_{i}-1\right)}{N(N-1)}
$$

Where: $\mathrm{n}$ is the total number of organisms of a particular species and $\mathrm{N}$ is the total number of individual of all species.

Tree species richness was analyzed using Margalef species richness index (d), which is used as a simple measure of species richness according to Margalef (1958).

$$
D_{x}=\frac{(S-1)}{\ln N}
$$

Where $\mathrm{S}=$ total number of species; $\mathrm{N}=$ total number of individuals in the site and $\mathrm{In}=$ natural logarithm.

Relative Density (RD), is used to assess species relative distribution of the town using;

$$
\mathrm{RD}=\left(\frac{\mathrm{ni}}{\mathrm{N}}\right) \times 100
$$

Where $\mathrm{n}_{\mathrm{i}}=$ the number of species and $\mathrm{N}=$ the total number of trees in the town.

\section{RESULTS AND DISCUSSION}

Floristic composition of amenity trees in the study area: A total of five hundred and thirty-nine (539) 
individual trees representing 26 species and 15 families were identified in the study areas. Some tree species found in A are Azadiractha indica, Gmelina arborea (plate 1) and Roystonea regia, Casuarina equisetifolia in B (plate 2) respectively. Arecaceae was the dominant family with 4 and 3 species in A and $B$ respectively. In terms of the number of trees individuals per family, Meliaceae was the dominant family in the A with 84 trees while Casuarinaceae was dominant in B with 92 trees (Table 1 and 2). In
Institution A, Azadiractha indica and Roystonea regia were the most dominant species with 84 and 47 individuals respectively (table 1). Casuarina equisetifolia and Polyalthia longifolia were identified as the most dominant with 92 and 65 individuals respectively in $\mathrm{B}$ (table 2 ). Trees species identified in the survey were higher for A (17) than B (9). However, Institution B had a total of 292 individual trees while Institution A had 247 trees.

Table 1: Floristic composition of amenity tree species in University of Port Harcourt

\begin{tabular}{llllll}
\hline S/N & Species & Family & Common names & Frequency & Relative density \\
\hline 1 & Azadiractha indica & Meliaceae & Neem tree & 84 & 34.00 \\
2 & Roystonea regia & Arecaceae & Royal palm & 47 & 19.18 \\
3 & Elaeis guinensis & Arecaceae & African palm tree & 25 & 10.20 \\
4 & Cocos nucifera & Arecaceae & Coconut tree & 9 & 3.67 \\
5 & Delonix regia & Fabaceae & Flamboyant tree & 3 & 1.22 \\
6 & Terminalia mantaly & Combretaceae & Madagascar almond & 38 & 15.51 \\
7 & Hura crepitans & Euphorbiaceae & Monkey no climb & 3 & 1.22 \\
8 & Caryota urens & Arecaceae & Fishtail palm & 13 & 5.30 \\
9 & Spondias cytherea & Anacardiaceae & June plum/ambarella & 3 & 1.22 \\
10 & Tectona grandis & Verbenaceae & Teak & 1 & 0.40 \\
11 & Mangifera indica & Anacardiaceae & Mango tree & 1 & 2.04 \\
12 & Terminalia catappa & Combretaceae & Almond tree & 6 & 0.40 \\
13 & Gmelina arborea & Verbenaceae & Gmelina & 2.04 \\
14 & Polyalthia longifolia & Annonaceae & Masquerade tree & 1 & 2.44 \\
15 & Treculia africana & Moraceae & African breadfruit & 1 & 0.40 \\
16 & Milicia excelsa & Moraceae & Iroko tree & 2 & 0.40 \\
17 & Spondias mombin & Anacardiaceae & Hog plum & 247 & 0.81 \\
& Total & & & 100 \\
\hline
\end{tabular}
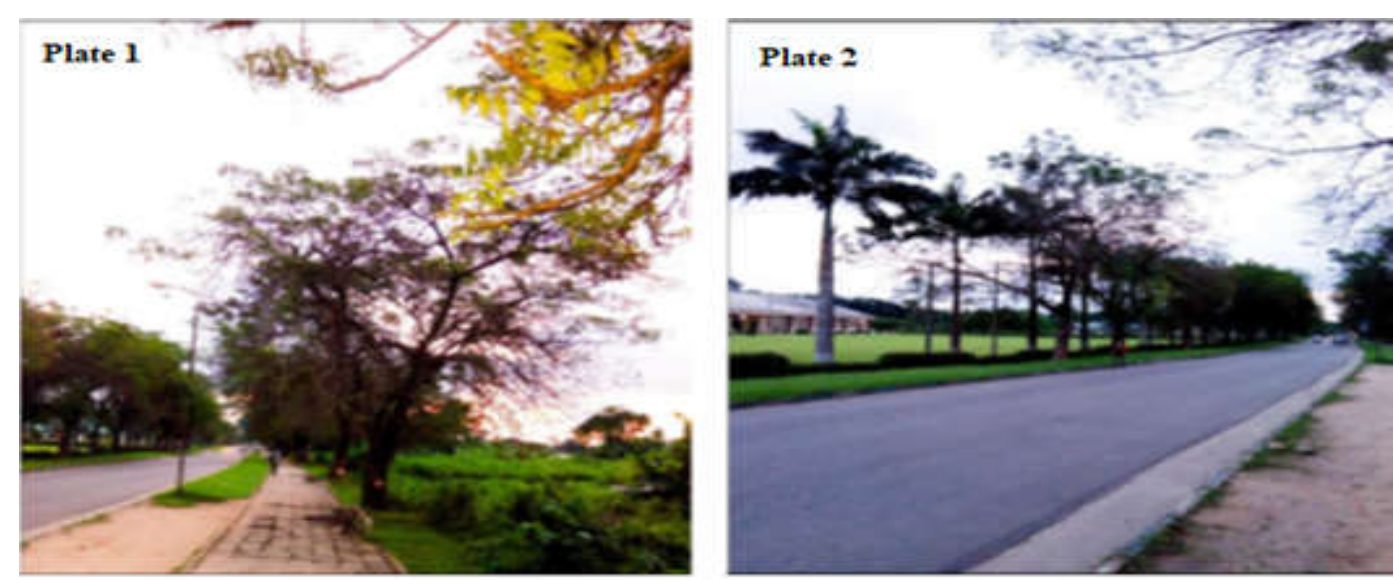

Plate 1: Amenity trees along major in Uniport and Plate 2: Amenity trees and palm along major road in RSU

Table 2: Floristic composition of amenity tree species in River State University

\begin{tabular}{llllll}
\hline S/N & Species & Family & Common Names & Frequency & Relative density \\
\hline 1 & Casuarina equisetifolia & Casuarinaceae & She oak tree & 92 & 31.50 \\
2 & Casuarina spp. & Casuarinaceae & & 42 & 14.38 \\
3 & Polyalthia longifolia & Annonaceae & Masquerade tree & 65 & 22.26 \\
4 & Roystonea regia & Arecaceae & Royal palm & 23 & 7.87 \\
5 & Gmelina arborea & Verbenaceae & Gmelina tree & 6 & 2.05 \\
6 & Elaeis guineensis & Arecaceae & African palm tree & 58 & 19.86 \\
7 & Cocos nucifera & Arecaceae & Coconut tree & 1 & 0.34 \\
8 & Terminalia ivorensis & Combretaceae & Black afara & 3 & 1.02 \\
9 & Delonix regia & Fabaceae & Flamboyant tree & 2 & 0.68 \\
& Total & & 292 & 100 \\
\hline
\end{tabular}

Diversity of amenity trees in Study areas: Tree diversity indices in terms of relative abundance,
Margalef idex, species richness, Shannon Wiener diversity $(\mathrm{H})$, and Simpson index for the study areas 
are presented in table 3 . The results of ShannonWiener diversity index $\left(\mathrm{H}^{\prime}\right)$ for Institutions A and B were: 2.02 and 1.67, while Shannon's maximum diversity index (Hmax) was 2.83 and 2.20 for $\mathrm{A}$ and $\mathrm{B}$ respectively (Table 3 ).

Table 3: Biodiversity indices for amenity trees in the study area

\begin{tabular}{lll}
\hline & Institution A & Institution B \\
\hline No. of Individual Trees & 247 & 292 \\
No. of Family & 8 & 6 \\
Diversity index (H') & 2.02 & 1.68 \\
Max. Diversity ( $\mathrm{H}_{\text {Max }}$ ) & 2.83 & 2.20 \\
Species Evenness (E $\left.\mathrm{E}_{\mathrm{H}}\right)$ & 0.71 & 0.76 \\
Simpson's Dominance index (D) & 0.81 & 0.79 \\
Specie richness & 17 & 9 \\
Margalef index & 2.90 & 1.41 \\
\hline
\end{tabular}

The result of tree species evenness in A and B was 0.71 and 0.76. Based on the result, Institution $A$ consistently showed a higher diversity index than $\mathrm{B}$ expect for the number of individual trees and species evenness.
Tree growth variables for amenity trees in the study area: Tree growth variables were measured and recorded for amenity trees in the university campuses. Tree height values ranges from $7.26 \mathrm{~m}-17.08 \mathrm{~m}$ and $6.66 \mathrm{~m}-16.14 \mathrm{~m}$ in Institutions A and B respectively (table 4 and 5). The species with the highest height values in $\mathrm{A}$ and $\mathrm{B}$ are Elaeis guineensis and Terminalia ivorensis respectively. Mean crown diameter ranges from $5.28 \mathrm{~m}-14.07 \mathrm{~m}$ in A (table 4) while B mean crown diameter ranges from 4.47 15.50 (table 5). Crown cover area recorded for Institutions A and B were $2520.35 \mathrm{~m}^{2}$ and $2465.13 \mathrm{~m}^{2}$ respectively. Casuarina equisetifolia recorded the highest crown cover area in B, covering $1124.38 \mathrm{~m}^{2}$ (5.62\%) of the sampled. In Institution A, Azadirachta indica recorded a crown cover area of $1074.29 \mathrm{~m}^{2}$ $(5.37 \%)$ of the study area (Table 4 .and.5).

Table 4: Tree growth variables of sampled trees in University of Port Harcourt

\begin{tabular}{llllllll}
\hline S/N & Species & N & Mean Height & Mean Dbh & Mean CD & Crown cover & \% Cover \\
\hline 1 & Azadiractha indica & 84 & 15.02 & 1.911 & 12.79 & 1074.29 & 5.37 \\
2 & Roystonea regia & 47 & 13.26 & 1.48 & 8.80 & 413.61 & 2.07 \\
3 & Elaeis guineensis & 25 & 17.08 & 2.34 & 6.35 & 158.57 & 0.79 \\
4 & Cocos nucifera & 9 & 10.37 & 0.78 & 7.99 & 71.95 & 0.36 \\
5 & Delonix regia & 3 & 13.40 & 0.98 & 14.07 & 42.22 & 0.21 \\
6 & Terminalia mantaly & 38 & 13.74 & 1.24 & 11.10 & 421.74 & 2.11 \\
7 & Hura crepitans & 3 & 12.65 & 2.43 & 12 & 36 & 0.18 \\
8 & Caryota urens & 13 & 11.06 & 0.99 & 6.56 & 85.26 & 0.43 \\
9 & Spondias cytherea & 3 & 8.40 & 0.87 & 6.88 & 20.63 & 0.10 \\
10 & Tectona grandis & 1 & 15.30 & 3.40 & 16.38 & 16.38 & 0.08 \\
11 & Mangifera indica & 5 & 14.42 & 3.66 & 12.88 & 64.38 & 0.32 \\
12 & Terminalia catappa & 1 & 11.73 & 4.32 & 13.27 & 13.27 & 0.07 \\
13 & Gmelina arborea & 5 & 7.26 & 0.78 & 6.88 & 34.39 & 0.17 \\
14 & Polyalthia longifolia & 6 & 14.06 & 1.03 & 5.28 & 31.65 & 0.16 \\
15 & Treculia africana & 1 & 16.30 & 3.62 & 13.40 & 13.40 & 0.07 \\
16 & Milicia excelsa & 1 & 8.71 & 0.47 & 5.13 & 5.13 & 0.03 \\
17 & Spondias mombin & 2 & 9.51 & 1.08 & 8.74 & 17.48 & 0.09 \\
\hline
\end{tabular}

Table 5: Tree growth variables of sampled trees in River State University

\begin{tabular}{llllllll}
\hline S/N & Species & N & $\begin{array}{l}\text { Mean } \\
\text { Height }\end{array}$ & $\begin{array}{l}\text { Mean } \\
\text { Dbh }\end{array}$ & $\begin{array}{l}\text { Mean } \\
\text { CD }\end{array}$ & $\begin{array}{l}\text { Crown } \\
\text { Cover }\end{array}$ & $\begin{array}{l}\text { \% } \\
\text { Cover }\end{array}$ \\
\hline 1 & Casuarina equisetifolia & 92 & 13.76 & 1.95 & 12.22 & 1124.38 & 5.62 \\
2 & Casuarina spp & 42 & 12.39 & 1.24 & 8.39 & 352.66 & 1.76 \\
3 & Polyalthia longifolia & 65 & 14.02 & 1.23 & 4.91 & 318.91 & 1.59 \\
4 & Roystonea regia & 23 & 6.66 & 1.02 & 4.47 & 102.91 & 0.51 \\
5 & Gmelina arborea & 6 & 12.99 & 3.68 & 10.47 & 62.81 & 0.31 \\
6 & Elaeis guineensis & 58 & 7.53 & 1.55 & 7.29 & 422.81 & 2.11 \\
7 & Cocos nucifera & 1 & 8.11 & 0.61 & 5.18 & 5.18 & 0.03 \\
8 & Terminalia ivorensis & 3 & 16.14 & 3.86 & 14.83 & 44.48 & 0.22 \\
9 & Delonix regia & 2 & 15.13 & 3.77 & 15.50 & 30.99 & 0.15 \\
\hline
\end{tabular}

Floristic composition of amenity trees in the study area: The taxonomy, diversity and distribution of tree growth variables for amenity trees in the study area have been documented. The urban trees play a vital part in the health and welfare of people who lives and works in the environment thereby promoting sustainable development. The study reveals that the sampled university campuses possess different species of trees. This finding is in agreement with the report of Babalola and Raji (2016) who also observed diverse tree species in academic area. The abundance and diversity of trees in the academic area may be as a result of the need to provide aesthetic environment and beautiful landscape for the University as well as provision of shade for student and staff. Generally trees are abundant in university environment because 
of the benefits derived from urban trees such as increased property values (Panduro and Veie, 2013; Babalola and Raji, 2016 and Rosato et al., 2017), control rainfall runoff and flooding (Livesley et al., 2016), improve wellbeing (Hall and Hodges, 2011; Taylor et al., 2001), purify the air and provide of shade (Agbelade et al., 2016) and are desired for beautification (Bello and Yacim, 2014). Mangifera indica, Delonix regia, Elaeis guineensis, Terminalia spp. e.t.c. were some of the species found in the study area. Aigbokhan (2014) and Ogwu et al., (2016) also found similar species in their study area due to the services such trees provides. However, the flora composition of the University Campuses especially University of Port Harcourt are under threat from infrastructural development and other anthropogenic activities. Similar findings have been reported by Wardle et al., (2004) and Ogwu et al., (2016). Chazdon, (2003), reported that as human population continue to grow, land use intensity increases and the negative effects of deforestation are likely to worsen hence sustainable management techniques are required to maintain the biodiversity and productivity of ecosystems (Reddy and Elanchezhian, 2008).

Diversity of amenity trees in Study areas: In this study biodiversity index was used to assess the level of biodiversity in the study area. According to Agbelade et al., (2016) biodiversity indices are generated to bring the diversity and abundance of species in different habitats to similar scale for comparison and the higher the value, the greater the species richness. Kacholi (2014) reports that understanding of tree species diversity, composition, and structure is very important in assessing sustainability of forest, species conservation, and ecosystems management. The results of Simpson's diversity index for the selected institutions are 0.81 for $\mathrm{A}$ and 0.79 for $\mathrm{B}$. The results of Shannon-Wiener diversity index $\left(\mathrm{H}^{\prime}\right)$ for the two universities are: 2.02 (A), and 1.68 (B) while species evenness (Shannon's equitability (index) gave 0.71 (A) and 0.76 (B). However, amenity tree species are more evenly distributed in Institution A compared to B. The Shannon-Wiener diversity index and species evenness of this study were lower than the values of Amonum et al.,(2019). The Shannon-Wiener index of the amenity trees of the study universities is higher than the value (0.84) obtained by Ogwu et al., (2016) for trees in University of Benin. The biodiversity indices obtained by Raji and Babalola (2018) for trees in University of Ilorin is similar with the finding of this study. Tree diversity is vital to tropical Forest biodiversity, because tree provide homes and resources to a wide variety of plant and animal species.
Growth parameters of amenity trees: The measurement and prediction of dbh, height and crown diameter of urban tree species will enable arborists, researchers, and urban forest managers to model costs and benefits, analyze alternative management scenarios, and determine the best management practices for sustainable urban forests (McPherson et al., 2005). This study describes the amenity tree composition and distribution of the selected universities, giving dbh, height and crown diameter of tree species community. Tree growth variables were generally higher for Institution A compared to B. The growth of trees in the studied universities is an indication of the level of conservation of tree species which urban forest can offer. This growth may be as a result of control and strict prohibition of tree felling within the campuses.

Conclusion: Basic information on amenity trees in University of Port Harcourt and River State University which can be used for the development of species databases in both institutions has been revealed. The research conducted a species diversity analysis proving the study area as diverse with medicinal and socio-economically importance species. Necessary action should be undertaken towards the sustainability of these trees and conservation of urban forest at large. Frequent inventory should be conducted for trees on campus to note their abundance, distribution and diversity.

\section{REFRENCES}

Agbelade, A. D., J C. Onyekwelu, J. C., and Apogbona, O. (2016).Assessment of Urban Forest Tree Species Population and Diversity in Ibadan, Nigeria. Environment and Ecology Research, 4(4): 185-192.

Aigbokhan, E.I. (2014). Annotated Checklist of Vascular Plants of Southern Nigeria - a quick reference guide to the Vascular Plants of Southern Nigeria: a systematic approach. Uniben Press, Benin City. 346.

Amonum, J.I., Jonathan, B.A., Japheth, H.D. (2019). Structure and Diversity of Tree Species at the College of Forestry and Fisheries, University of Agriculture Makurdi, Benue State, Nigeria. 5(1): 20-27 ISSN No. (Online) 2454-9487

Armenteras, D., Rodriguez, N. and Retana, J. (2009). Are conservation strategies effective in avoiding the deforestation of the Colombian Guyana Shield? Biological Conservation 42: 1411-1419 
Babalola, F.D. and Raji, I.A. (2016).Perception of Urban Trees at Main Campus of University of Ilorin, Ilorin, Kwara State, Nigeria. Applied Tropical Agriculture. 21(1): 60-67

Bello, O.M. and Yacim, A.J. (2014). An Assessment of the Impact of Tree Shade on Rental Value of Residential Property in Maiduguri, North Eastern, Nigeria. Paper presented at the FIG Congress, Kuala Lumpur, Malaysia (16 - 21 June 2014). $1-18$

Chazdon, R.L. (2013). Tropical Forest Recovery: Legacies of Human Impact and Natural Disturbances. Prospect. Plant Ecology. 6: 51-71

Ezeabasili, A. C. C., Iloghalu, I. E., Okoro, B. U., and Manafa, I. F. (2015).Sustainable Urban Forestry in Nigerian Built Environments. Journal of Scientific Research \& Reports. 5(7). $524-531$

Francisco M. P. Gonçalves, Rasmus Revermann, Amândio L. Gomes, Marcos P. M. Aidar, Manfred Finckh, and Norbert Juergens (2017): Tree Species Diversity and Composition of Miombo Woodlands in South-Central Angola: A Chrono sequence of Forest Recovery after Shifting Cultivation. Hindawi International Journal of Forestry Research, Volume 2017, Article ID 6202093, 13 pages https://doi.org/10.1155/2017/6202093

Hall, C.R., and Hodges, A.W. (2011). Economic, Environmental and Well-Being Benefits of Lifestyle Horticulture. Chronica Horticulturae. 51(4): 5-8

Kent, M. and Coker, P. (1992): Vegetation description and analysis: a practical approach. Belhaven press London: 363

Kumar, M. ; Bhatt, V. P. ; Rajwar, G. S., (2006). Plant and soil diversities in a sub-tropical forest of the Garhwal Himalaya. Ghana Journal of Forestry. 19-20:1-19

Livesley, S.J., McPherson, E.G. and Calfapietra, C. (2016). The Urban Forest and Ecosystem Services: Impacts on Urban Water, Heat, and Pollution Cycles at the Tree, Street, and City Scale. J. Environ. Qual. 45: 119-124

Magurran, A.E. (2004): Measuring Biological Diversity. Blackwell Publishing, Boston
Margalef, R. (1958). Temporal succession and spatial heterogeneity in phytoplankton. In: BuzzatiTraverso (ed.). Perspectives in Marine biology. University of California Press, Berkeley, 323 347.

Mani, S. and Parthasarathy, N. (2006). Tree diversity and stand structure in inland and coastal tropical dry evergreen forests of peninsular India. Current Science. 90: 1238-1246

McPherson E.G, Simpson J.R, Peper, Paula J, Maco SE, Xiao Q (2005). Municipal Forest Benefits and Costs in Five US Cities. J. For. 103(8): 411416(6).

Ogwu, M.C., Osawaru, M.E. and Obayuwana, O.K. (2016). Diversity and Abundance of Tree Species in the University of Benin, Benin City, Nigeria. Appl. Trop. Agric. 21 (3) 46-54

Omoro, L.M.A., Pellikka, P.K.E. and Rogers, P.C. (2010). Tree species diversity, richness, and similarity between exotic and indigenous forests in the cloud forests of Eastern Arc Mountains, Taita Hills, Kenya. Journal of Forestry Research. 21(3): 255-264

Panduro, T.E. and Veie, K.L. (2013). Classification and valuation of urban green spaces - A hedonic house price valuation. Landscape and Urban Planning. 120: $119-128$.

Raji I. A. and Babalola F. D. (2018). Assessment of Tree Diversity and Abundance in University of Ilorin Campus: Towards Conservation. Proceedings of $6^{\text {th }}$ NSCB Biodiversity Conference; Uniuyo. 443-450

Reddy, D. V. and Elanchezhian, N., (2008). Evaluation of tropical tree leaves as ruminant feedstuff based on cell contents, cell wall fractions and polyphenolic compounds. Livest. Res. Rural Dev. 20 (5): 77

Rosato, P., Breil, M., Giupponi, C. and Berto, R. (2017). Assessing the Impact of Urban Improvement on Housing Values: A Hedonic Pricing and Multi-Attribute Analysis Model for the Historic Centre of Venice. Buildings. 7(112): $1-24$

Shannon, C. E., \& Weaver, W. (1949): The Mathematical theory of communication. Urbana, University Illinois Press. 
Simpson, E.H. (1949). Measurement of diversity. Nature. 163: 688.

Suratman, M. N. (2012). Tree Species Diversity and Forest Stand Structure of Pahang National Park, Malaysia.In: Biodiversity Enrichment in a Diverse World. Chapter 18. INTECH. 473-492

Taylor, A.F., Kuo, F.E. and Sullivan, W.C. (2001) COPING WITH ADD - The Surprising Connection to Green Play Settings [in] Environment and Behavior. 33(1): 54 - 77
United Nations (2006). World Population Prospects: The 2006 Revision and World Urbanization Prospects: The 2005 Revision, Population Division of the Department of Economic and Social Affairs of the United Nations Secretariat, http://esa.un.org/unpp.

Wardle, D.A., Walker, L.R. and Bardgett, R.D. (2004). Ecosystem properties and forest decline in contrasting long-term chronosequence. Sci. 305: $509-513$ 